\title{
STUDI EKSPERIMEN PENGOLAHAN TEPUNG UMBI SUWEG
}

\author{
Ida Ayu Satya Dwikandana, Damiati, Ni Made Suriani \\ Jurusan Pendidikan Kesejahteraan Keluarga, Fakultas Teknik dan Kejuruan \\ Universitas Pendidikan Ganesha \\ Singaraja, Indonesia \\ e-mail : dayuchaca0108@gmail.com,damiati@undiksha.ac.id, \\ made.suriani@undiksha.ac.id
}

\begin{abstract}
Abstrak
Penelitian ini bertujuan untuk (1) mendeskripsikan proses pembuatan tepung umbi suweg (2) mengukur kandungan zat gizi tepung umbi suweg (3) mendeskripsikan kualitas tepung umbi suweg dilihat dari segi warna, aroma, dan tekstur. Objek dalam penelitian ini adalah proses pembutaan tepung umbi suweg, kandungan gizi tepung umbi suweg, dan kualitas tepung umbi suweg dilihat dari segi warna, aroma, dan tekstur. Jenis penelitian ini adalah penelitian eksperimen. Metode yang digunakan dalam penelitian ini adalah metode observasi. Teknik analisis data yang digunakan yaitu deskriptif kuantitatif. Berdasarkan hasil analisis data, ditemukan bahwa (1) proses pembuatan tepung umbi suweg melalui 8 tahapan yaitu pengupasan;pengirisan, pencucian tahap I, perendaman, pencucian tahap II, pengukusan, penjemuran, penggilingan;pengayakan, dan pengemasan.(2) kandungan zat gizi tepung umbi suweg meliputi air 11,98\%, abu $4,32 \%$, protein 5,44\%, lemak 1,80\%, karbohidrat 76,42\%, pati 56,07\% dan kalori 343,79kkal.

(3) kualitas tepung umbi suweg dilihat dari segi warna berada pada kategori baik dengan warna yang sesuai dengan yang diharapkan yaitu putih kecoklatan. Dari segi aroma berada pada kategori baik dengan hasil sesuai yaitu khas aroma umbi suweg. Dari segi tekstur berada pada kategori baik dengan hasil halus.
\end{abstract}

Kata kunci : kandungan gizi, tepung, umbi suweg

\begin{abstract}
This research is aimed to find out: (1) described the prosess of making suweg tuber flour, (2) measured nutrient content of suweg tuber flour, (3) described the quality of suweg tuber flour in terms of color, flavor dan texture. The object in this research was making processed of suweg tuber flour, nutrient content of suweg tuber flour, and quality of suweg tuber flour in terms of color, flavor dan texture. The design of this research was laboratory experiment research. The method of this research was observation method. Data analysis techniques used are quantitative descriptive. The results of the research are: (1) the proses of making suweg tuber flour through eight steps that is stripping;incision, first washing, soaking, second washing, steaming, drying, grinding;sifting, and packaging, (2) nutrient content of suweg tuber flour is $11,98 \%$ of water; $4,32 \%$ of ash; $5,44 \%$ of protein; $1,80 \%$ of fat; $76,42 \%$ of carbohydrate; $56,07 \%$ of starch and $343,79 \mathrm{kkal}$ of calories, (3) the quality of suweg tuber flour in terms of color, it is in a good category with colors that are as expected, namely brownish white. In terms of flavor, it is in a good category too with flavor that are as expected, namely unique of suweg tuber. And the last, in terms of texture. From the texture suweg tuber flour is in a good point with smooth texture.
\end{abstract}

Keywords : flour, nutrient content, suweg tuber 


\section{PENDAHULUAN}

Indonesia merupakan salah satu Negara yang terdiri dari berbagai macam pulau yang memiliki keanekaragaman budaya serta kekayaan alam. Jika di lihat dari kondisi alam di Indonesia, Negara kita memiliki potensi yang cukup besar dalam hal hasil buminya. Suburnya tanah di Indonesia menjadikan Negara ini sangat berlimpah

dengan hasil pertanian ataupun perkebunanya. Tugas kita sebagai Warga Negara Indonesia adalah menjaga, memanfaatkan serta mengolah hasil bumi tersebut dengan efisien dan tentunya bermanfaat di masyarakat. Hasil bumi pada bidang perkebunan sangat bermacammacam mulai dari berbagai jenis sayuran, buah-buahan, kacang-kacangan, umbiumbian dan lain sebagainya. Salah satu jenis umbi-umbian yang cukup mudah ditemui namun tidak umum digunakan sebagai bahan makanan yaitu umbi suweg.

Suweg yang dalam bahasa latinnya disebut Amorphophallus paeoniifolius, tanaman yang biasa tumbuh liar di Indonesia. Tanaman ini dapat tumbuh di hutan, kebun-kebun, lereng-lereng gunung di atas tanah pada ketinggian 1 sampai 700 meter di atas permukaan laut. Tanaman ini hidup di bawah tegakan pohon lain seperti di bawah rumpun bambu, di bawah jati, atau di bawah mahoni.
Suweg merupakan famili Araceae yang merupakan tumbuhan semak (herba) dengan umbi di dalam tanah. Suweg banyak tumbuh di hutan karena hanya memerlukan penyinaran matahari 50-60\% sehingga sangat cocok untuk tanaman di bawah naungan.

Umbi suweg merupakan salah satu hasil bumi yang cukup di gemari di desadesa, namun tidak cukup di kenal di daerah perkotaan. Tak banyak pula pedangangpedangang yang menjual jenis umbi yang satu ini. Biasanya umbi suweg hanya di konsumsi di lingkungan keluarga saja yang kebetulan kebunnya di tumbuhi oleh tanaman suweg ini. Umbi suweg dalam keadaan segar umumnya diolah dengan cara dikukus kemudian disajikan bersama dengan kelapa parut. Selain dengan cara dikukus, belum banyak ditemui varian pengolahan dari umbi suweg itu sendiri. Sehingga, pemanfaatan umbi suweg sebagai alternatif bahan pangan belum banyak ditemui dan belum dimanfaatkan secara maksimal karena pengolahan yang umum digunakan hanya dengan cara dikukus saja dan tidak diolah menjadi jenis bahan pangan lainnya.

Jika di lihat dari kandungan gizi umbi suweg segar dan jika dibandigkan dengan kandungan gizi umbi talas kimpul segar, maka dapat dilihat, bahwa :

Tabel 1. Kandungan gizi umbi suweg dan umbi talas kimpul

\begin{tabular}{|c|c|c|}
\hline \multirow{2}{*}{ Analisis } & Umbi suweg *) & $\underset{* *}{\text { Umbi talas kimpul }}$ \\
\hline & $\begin{array}{l}\text { per 100g (Umbi } \\
\text { segar) }\end{array}$ & $\begin{array}{l}\text { per 100g } \\
\text { (Umbi segar) }\end{array}$ \\
\hline Energy & 74 & \\
\hline Protein & 1,40 & 2,81 \\
\hline Lemak & 0,10 & 0,08 \\
\hline Karbohidrat & 17,20 & 28,66 \\
\hline Kalsium & 42,00 & - \\
\hline Posfor & 46 & - \\
\hline Iron & 1,30 & - \\
\hline Vit B1 & 0,04 & - \\
\hline Vit C & 2,3 & - \\
\hline Air & - & 67,26 \\
\hline Abu & - & 1,19 \\
\hline
\end{tabular}


Jurnal Bosaparis: Pendidikan Kesejahteraan Keluarga

Volume 9, Nomor 3, November 2018

Berdasarkan tabel tersebut, maka dapat dilihat bahwa kandungan gizi talas kimpul lebih tinggi dan kandungan pati diantara keduannya memiliki perbedaan sekitar $2,43 \%$, dimana kandungan pati talas kimpul lebih tinggi.

Disamping itu, berdasarkan penelitian yang dilakukan oleh Desak Nyoman Kartika dari Universitas Pendidikan Ganesha pada tahun 2017, Penelitian yang dilakukan adalah "Substitusi Tepung Talas Kimpul Menjadi Kue Kering Sagon", dimana dalam penelitian ini juga menggunakan bahan makanan berjenis umbi-umbian. Penelitian ini memperkuat bahwa jenis bahan makanan yang berasal dari umbi, dapat diolah menjadi tepung.

Sehingga, berdasarkan data-data diatas dan perbedaan kandungan pati sekitar 2,43\% lebih kecil dari umbi talas kimpul, umbi suweg memiliki kemungkinan dapat diolah menjadi tepung, yang nantinya juga dapat dijadikan bahan pangan alternatif sebagai pengganti tepung terigu atau tepung yang lainnya untuk diolah menjadi kue. Kandungan pati yang terbilang tinggi menjadikan umbi suweg berpotensi untuk diolah menjadi tepung

Tabel 2. Standar nasional tepung singkong

\begin{tabular}{|c|c|c|c|}
\hline No & Jenis Uji & Satuan & Persyaratan \\
\hline 1 & Keadaan & - & \\
\hline 1.1 & $\mathrm{Bau}$ & - & Khas Singkong \\
\hline 1.2 & Rasa & - & Khas Singkong \\
\hline 1.3 & Warna & - & Putih \\
\hline 2 & Benda Benda Asing & - & Tidak boleh ada \\
\hline 3 & Serangga & - & Tidak boleh ada \\
\hline 4 & Jenis Pati & - & Khas singkong \\
\hline 5 & $\mathrm{Abu}, \% \mathrm{~b} / \mathrm{b}$ & - & Maks. 1.5 \\
\hline 6 & Air, $\%$ b/b & - & Maks. 12 \\
\hline 7 & $\begin{array}{l}\text { Derajat Putih, \% b/b } \\
\text { (BaSO4 =100\%) }\end{array}$ & - & Min. 85 \\
\hline 8 & Serat Kasar & - & Maks. 4 \\
\hline 9 & $\begin{array}{l}\text { Derajat asam } \\
\mathrm{ml} \mathrm{N} \mathrm{NaOH} / 100 \mathrm{~g}\end{array}$ & - & Maks. 3 \\
\hline 10 & Asam sianida & $\mathrm{mg} / \mathrm{kg}$ & Maks. 40 \\
\hline 11 & $\begin{array}{l}\text { Kehalusan (lolos ayakan } 80 \\
\text { mesh), \% }\end{array}$ & - & Min. 80 \\
\hline 12 & Pati, \% b/b & - & Mn. 75 \\
\hline 13 & $\begin{array}{l}\text { Bahan tambahan makanan } \\
\text { (bahan pemutih dan } \\
\text { pematang tepung) }\end{array}$ & - & Sesuai SNI 01-0222-1995 \\
\hline 14 & Cemaran logam & - & \\
\hline 14.1 & Timbal $(\mathrm{Pb})$ & $\mathrm{mg} / \mathrm{kg}$ & \\
\hline 14.2 & Tembaga (cu) & $\mathrm{mg} / \mathrm{kg}$ & Maks 10,0 \\
\hline 14.3 & Seng (Zn) & $\mathrm{mg} / \mathrm{kg}$ & Maks. 40,0 \\
\hline 14.4 & Raksa $(\mathrm{Hg})$ & $\mathrm{mg} / \mathrm{kg}$ & Maks. 0,05 \\
\hline 15 & Arsen (As) & $\mathrm{mg} / \mathrm{kg}$ & Maks. 0,5 \\
\hline 16 & Cemaran Mikroba & & \\
\hline 16.1 & Angka lempeng & Koloni/g & Maks. $1.0 \times 10^{9}$ \\
\hline 16.2 & 16E Coli & Koloni/g & Maks. 10 \\
\hline 16.3 & Kapang & Koloni/g & Maks. $1.0 \times 10^{4}$ \\
\hline
\end{tabular}


Jurnal Bosaparis: Pendidikan Kesejahteraan Keluarga

Volume 9, Nomor 3, November 2018

Berdasarkan tabel diatas, maka umbi suweg, memenuhi standar untuk diolah menjadi tepung, dimana kandungan yang harus diperhatiakan adalah jenis protein, abu, air, dan pati.

Tepung adalah hasil dari proses penggilingan yang menghasilkan serbuk halus. Setiap proses pembuatan tepung membutuhkan penanganan yang berbedabeda. Tepung yang berasal dari biji-bijian tentu berbeda penanganannya dengan tepung yang berasal dari umbi-umbian. Sehingga diperlukan cara yang berbeda. Dalam proses pembuatan tepung umbi suweg ini disesuaikan dengan karakteristik dari umbi suweg tersebut.

Kandungan gizi yang jelas juga merupakan penentu dari kualitas bahan makanan. Menurut Chairinniza K. Graha mengemukakan tentang pengertian gizi yang berarti gizi merupakan unsur yang terkandung dalam makanan dimana unsurunsur tersebut dapat memberikan manfaat bagi tubuh yang mengkonsumsinya sehingga menjadi sehat. Oleh karena itu diperlukan rincian yang jelas mengenai kandungan gizi yang terdapat pada umbi suweg, agar nantinya dapat menjadi bahan pertimbangan dalam dunia pangan.

Pada umumnya tepung digunakan sebagai bahan dasar pada pembuatan berbagai jenis kue dan juga roti. Tepung yang umum digunakan adalah tepung terigu, tepung beras, tepung tapioka, tepung ketan dan tepung maizena. Berdasarkan hal tersebut maka pemilihan umbi suweg sebagai bahan dasar pembuatan tepung umbi suweg, menjadi hal yang tepat karena akan meningkatkan jenis bahan pangan alternatif dalam dunia boga. Penulis mencoba membuat tepung umbi suweg dan mencari kualitas tepung umbi suweg ditinjau dari segi aroma, warna, dan tekstur sehingga nantinya tepung umbi suweg dapat digunakan sebagai tepung pengganti dalam pembuatan aneka kue.

\section{METODE}

Dalam hal ini penelitian yang dilakukan adalah Penelitian Eksprimen. Penelitian eksperimen adalah suatu metode penelitian yang dilakukan melalui suatu percobaan sehingga didapatkan hasil berupa pengetahuan yang baru atau data baru serta kebenaran yang diperoleh melalui percobaan.

Penelitian ini diawali dengan penentuan masalah yang ingin diangkat kemudian dilanjutkan dengan tahap perumusan masalah. Setelah permasalahan selesai dirumuskan, langkah berikutnya yaitu observasi awal kemudian dilanjutkan dengan pengumpulan data-data pendukung. Setelah data terkumpul maka dilakukan tahap berikutnya yaitu menentukan langkah eksperimen dan pembutaan instrumen penelitian. Kemudian, tahap berikutnya yang dilakukan yaitu mengumpulkan bahan utama yang dibutuhkan dalam penelitian dan dilanjutkan dengan tahap pra eksperimen. Dalam tahap pra eksperimen ini dilakukan dengan mengacu pada penelitian yang dilakukan oleh Desak Nyoman Kartika pada tahun 2017 dari Universitas Pendidikan Ganesha tentang proses pembuatan tepung talas kimpul dan juga proses pembuatan tepung singkong yang dilakukan oleh SEAFAST Center.

Setelah melaksanakan pra ekperimen pengolahan umbi suweg menjadi tepung umbi suweg, dilakukan tahap evaluasi guna mengetahui kekurangan pada saat melakukan langkah ekperimen. Setelah tahap evaluasi selesai dilanjutkan dengan tahap eksperimen. Setelah itu dilakukan proses pengambilan data. Tepung umbi suweg yang telah jadi akan diuji laboratorium untuk mengetahui kandungan gizinya menggunakan lembar uji laboratorium. Kemudian, tepung umbi suweg diuji kualitasnya dari aspek warna, aroma dan tekstur melalui lembar uji kualitas. Lembar uji kualitas di diisi oleh panelis, kemudian jika data telah terkumpul akan dijabarkan secara sistematis dengan menggunakan analisis deskriptif kuantitatif. Tahap akhir yaitu pengambilan kesimpulan. 
Jurnal Bosaparis: Pendidikan Kesejahteraan Keluarga

Volume 9, Nomor 3, November 2018

Dalam penelitian ini yang menjadi variabel adalah (1) Proses pengolahan tepung umbi suweg, (2)Kandungan gizi tepung umbi suweg (3) Kualitas tepung umbi suweg dari segi warna, aroma dan tekstur.

Metode pengumpulan data yang digunakan dalam penelitian ini adalah metode observasi.Metode observasi dilakukan untuk mengumpulkan data mengenai umbi suweg. Metode observasi ini juga digunakan untuk mengumpulkan data dari para panelis terhadap kualitas tepung umbi suweg dilihat dari aspek warna, aroma, dan tekstur. Disamping itu, metode ini digunakan pula untuk pengambilan data berupa kandungan gizi yang terdapat pada tepung umbi suweg melalui uji laboratorium.

Pada penelitian ini digunakan uji laboratorium, yaitu uji pada laboratorium untuk mengetahui kandungan gizi pada tepung umbi suweg. Instrumen yang digunakan adalah lembar uji laboratorium. Serta digunakana juga uji organoleptik, yaitu pengujian yang didasarkan pada proses pengindraan. Bagian organ tubuh yang berperan dalam pengindraan adalah mata, telinga, indra pencicip, indra pembau dan indra perabaan atau sentuhan. Pada uji organoleptik ini digunakan uji mutu hedonik, yaitu menyatakan kesan tentang baik atau buruk. Uji mutu hedonik ini digunakan untuk mengetahui tanggapan panelis megenai kualitas tepung umbi suweg dilihat dari aspek warna, aroma dan tekstur.

Panelis yang digunakan dalam penelitian ini adalah panelis terbatas terdiri dari 3-5 orang yang mempunyai kepekaan tinggi. Panelis ini mengenal dengan baik faktor-faktor dalam penilaian organoleptik dan mengetahui cara pengolahan dan pengaruh bahan baku terhadap hasil akhir.

Dalam penelitian ini, penulis memilih 5 orang panelis, dengan cara memberikan check list (v) sesuai kriteria yang telah ditetapkan pada uji kualitas tepung umbi suweg berdasarkan skala mutu hedonik. Instrumen yang di gunakan adalah lembar uji kualitias. adalah :

Nilai yang diberikan pada setia panelis

Tabel 3.

Skala Mutu Hedonik dan Skala Numerik

\begin{tabular}{cc}
\hline Skala Mutu Hedonik & Skala Numerik \\
\hline Baik & 3 \\
\hline Cukup & 2 \\
\hline Buruk & 1 \\
\hline & $M=\frac{2 x}{}$
\end{tabular}

Dalam penelitian ini penulis menggunakan metode analisis deskriptif kuantitatif. Metode analisis deskriptif kuantitatif adalah suatu cara pengolahan data yang dilakukan dengan jalan menyusun angka secara sistematis dalam bentuk presentase mengenai suatu objek yang akan diteliti, sehingga diperoleh kesimpulan umum.

Dalam penelitian ini digunakan pedoman penghitungan menurut Arikunto (2002 : 264 ) sebagia berikut :
Keterangan Rumus :

$M=$ Mean ( rata-rata )

$\sum \mathrm{x}=$ Jumlah masing-masing skor

$\mathrm{N}=$ Jumlah subyek/sampel

Untuk menentukan kualitas tepung umbi suweg dianalisis berdasarkan mean

(M) dan standar deviasi (SD) dengan mengkonversikan rata-rata presentase ke dalam kriteria sebagai berikut: 
Jurnal Bosaparis: Pendidikan Kesejahteraan Keluarga

Volume 9, Nomor 3, November 2018

$M=$ Mean atau rata-rata yang dicari dengan

rumus $\div$

$M={ }_{2} \times$ (skor maks. + skor $\min$ )

$\mathrm{SD}=$ Standar deviasi yang dicari dengan

rumus :-

$\mathrm{SD}={ }_{1}{ }_{6} \times($ skor maks. - skor min. $)$

Skor maksimum $\quad: 3$

Skor minimum $\quad: 1$

Berdasarkan rumus diatas, maka data yang sudah terkumpul akan dicari konversinya. Sehingga mendapatkan hasil sebagai berikut :

$M=1_{2} \times$ tskor maks. + skor min.)

$M=1_{2} \times(\vec{J}+1)$

$M=12 \times 4$

$M=2$

$\mathrm{SD}={ }^{1} 6 \underline{\bar{x}}$ (skor maks. + skor min.)

$\mathrm{SD}=1 \times(3-1) 6$

$\mathrm{SD}=0,33$

Acuan pengambilan keputusan yang digunakan untuk menentukan kualitas tepung umbi suweg dari segi warna, aroma dan tekstur berdasarkan rumus pedoman konversi skala tiga adalah sebagai berikut: (Koyan, 2008:122)

Rumus pedoman konvensi skala 3 (Tiga)

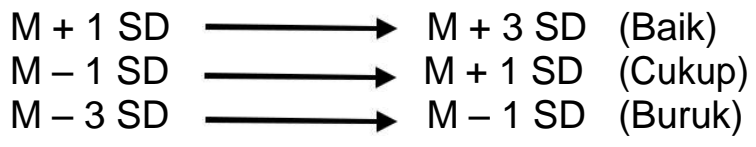

Keterangan Rumus :

$\mathrm{M}=$ Mean (rata-rata)

$\mathrm{SD}=$ Standar Deviasi

Bedasarkan rumus pedoman konversi PAN dengan skala 3 maka diperoleh :

$2,33-3,00=$ Baik

$1,67-2,32=$ Cukup

$1,00-1,67=$ Buruk

\section{HASIL DAN PEMBAHASAN}

Penelitian yang dilaksanakan oleh penulis ini dilaksanakan di Laboratorium Produksi Jurusan Pendidikan Kesejahteraan Keluarga Program Studi Tata Boga dan di Laboratorium Fakultas Teknologi Pangan Universitas Udayana. Metode yang digunakan dalam penelitian ini adalah metode observasi dan hasil pengolahan umbi suweg menjadi tepung umbi suweg akan diuji melalui uji laboratorium dan uji kualitas (Organoleptik) yang dilihat dari segi warna, aroma dan juga tekstur. Dalam pelaksanaan uji kualitas ini diperlukan adana beberapa orang panelis, dimana panelis yang digunakan yaitu panelis terbatas yang berjumlah 5 orang. Panelis ini terdiri dari 3 orang Dosen dan 2 orang Guru.

Pengumpulan data pada penelitian ini dilaksanakan di Jurusan PKK UNDIKSHA Singaraja dan juga di Jurusan Tata Boga SMK PGRI 4 Denpasar. Pengumpulan data dilaksanakan pada tanggal 16 Agustus 2018 sampai 18 Agustus 2018. Istrumen pengumpulan data yang digunakan adalah lembar uji kualitas tepung umbi suweg.

Hasil dari penelitaian ini adalah tepung umbi suweg yang di uji laboratorium dengan parameter kandungan zat gizi karbohidrat, lemak, protein, air, abu, dan juga pati. Sedangkan dalam uji kualitas yaitu warna, aroma dan tekstur. Data yang diperoleh kemudian dianalisis menggunakan teknik analisis kuantitatif, sehingga diperoleh kesimpulan pada proses pembuatan tepung umbi suweg, kandungan gizi pada tepung umbi suweg, dan kualitas tepung 
Jurnal Bosaparis: Pendidikan Kesejahteraan Keluarga

Volume 9, Nomor 3, November 2018

umbi suweg dari segi warna, aroma dan juga tekstur. Dalam hal ini digunakan skala hutu hedonik yaitu dengan kriteria baik, cukup dan buruk.

Tepung umbi suweg yang diuji kualitasnya dari segi warna, aroma, dan juga tekstur merupakan hasil eksperimen laboratorium yang dilaksanakan mengacu pada resep standar proses pembuatan tepung talas kimpul (Desak Kartika, 2017) dan proses pembuatan tepung singkong (Southeast Asian Food And Agricultural Science and Technology (SEAFAST) Center) yang telah ditetapkan setelah melakukan uji coba pendahuluan (pra Eksperimen) yang telah diuraikan pada bab III.

Adapun resep standar tersebut, yaitu: (1) persiapan bahan. Bahan yang digunakan dalam pembuatan tepung umbi suweg antara lain umbi suweg segar, air, garam. (2) Peralatan-peralatan yang digunakan dalam penelitian pembuatan tepung umbi suweg ini harus dipastikan alat-alat yang dibutuhkan dalam keadaan yang bersih dan steril. Pastikan pula peralatan yang digunakan terbebas dari debu dan kotoran lainnya. Peralatan harus dicuci terlebih dahulu kemudian di keringkan dengan lap yang bersih dan bisa menyerap air. Peralatan yang digunakan antara lain pisau, talenan, waskom, tray, blender, ayakan, panci kukusan dan timbangan.

Proses pembuatan tepung umbi suweg ini mengacu pada proses pembuatan tepung talas kimpul yang dilakukan oleh Desak Nyoman Kartika dari Universitas Pendidikan Ganesha serta proses pembuatan tepung singkong (SEAFAST). Acuan ini diambil karena talas kimpul, singkong dan umbi suweg merupakan bahan pangan yang sama-sama berasal dari kelompok umbi-umbian.

Berdasarkan penelitain tersebut, peneliti mengambil acuan pada langkahlangkah pembuatannya. Dalam penelitian tersebut, langkah-langkah pembuatan tepung terdiri dari 7 tahapan yaitu pengupasan;pengirisan, pencucian tahap I,

perendaman, Pencucian tahap II, penjemuran, penggilingan;pengayakan, dan pengemasan. (Desak Kartika, 2017). Sedangkan dalam proses pembuatan tepung umbi suweg, selain 7 tahapan yang beracuan pada pembuatan tepung talas kimpul, ada langkah yang ditambahkan yaitu proses pengukusan.

Sebelum memasuki tahap pengukusan, ada beberapa langkah yang harus dilakukan. Yang pertama yaitu proses pencucian dan perendaman, dimana dalam proses pencuciannya harus menggunakan air yang mengalir dan proses pencucian dilakukan sebanyak 2 kali, sedangkan dalam

proses perendamannya ditambahkan larutan garam dengan tujuan untuk menetralkan kandungan zat-zat yang ada pada umbi suweg, menghilangkan rasa gatal serta menghilangkan getah pada umbi suweg. Proses perendaman ini dilakukan selama satu malam, atau sekurangkurangnya selama 12 jam (Drajat, 1987).

Setelah mengalami proses perendaman dan pencucian tahap 2, langkah berikut yang dilakukan yaitu proses pengukusan, dimana hal ini dilakukan karana bertujuan untuk menyesuaikan karakter dari umbi suweg yang sedikit kurang aman jika diproses tanpa dimasak terlebih dahulu (Affy,2010). Meskipun hasil olahan ini nantinya akan mengalami proses pemasakan juga ketika akan diolah menjadi produk makanan, tetapi penulis menginginkan produk bahan makanan ini benar-benar terjaga kualitas hieginenya serta produk yang dihasilkan benar-benar aman dari zat-zat yang berbahaya bagi tubuh sehingga harus dinetralkan dengan jalan melalui proses pengukusan. Prinsip proses pengukusan juga akan menurunkan aktifitas bahkan mematikan mikroorganisme berbahaya. Pada Umbi suweg, proses pengukusan ini juga berpengaruh pada pati yang nantinya akan dihasilkan, dimana pada proses pengukusan akan meningkatkan kadar pati yang dihasilkan (Affy,2010). Disamping itu, Pada saat proses perendaman hanya menggunakan air bersama dengan larutan garam, sehingga setelah proses perendaman perlu dilakukan proses pegukusan lagi, agar racun dan juga rasa gatal yang ada pada umbi suweg benar- 
Jurnal Bosaparis: Pendidikan Kesejahteraan Keluarga

Volume 9, Nomor 3, November 2018

benar hilang. Proses penghantaran panas yang terjadi pada saat proses pengukusan akan membantu zat-zat berhaya yang terkandung pada umbi suweg benar-benar larut. (Drajat, 1987).

Setelah melalui proses pemasakan, langkah berikutnya yang dilakukan adalah proses penjemuran. Proses penjemuran dilakukan dibawah sinar matahari langsung selama 3-4 hari, untuk menghasilkan prosuk yang benar-benar kering. Jika dalam keadaan matahari kurang terik, proses ini bias berlangsung selama 7 hari. Proses

pengeringan ini dilakukan untuk mengurangi/menghilangkan kadar air yang terkandung pada umbi suweg. Setelah umbi suweg benar-benar kering, prsos selanjutnya yaitu penggilingan/penghalusan umbi suweg kering. Dalam tahap ini alat yang digunakan adalah blender, serta saringan yang digunakan berukuran 600 mesh agar menghasilkan butiran-butiran tepung yang halus dan terbebas dari kotorang-kotoran.

Cara pembuatan pembuatan tepung umbi suweg, antara lain: (1) Tahap Pengupasan dan Pengirisan. Umbi suweg dikupas kulitnya dan dibersihkan dari akarakarnya. Setelah itu umbi suweg diris tipistipis. yang bertujuan untuk mempercepat proses pengeringan ketika dijemur. (2) Proses pencucian tahap I. Pada proses ini dilakukan proses pencucian umbi suweg yang sudah dikupas dan diiris yang berfungsi untuk menghilangkan sisa kotoran yang menempel pada umbi suweg. (3) proses perendaman. Berikutnya umbi suweg yang telah dicuci, direndam dengan larutan air garam dilakukan selama 1 malam yang bertujuan untuk menghilangkan rasa gatal. (4) pencucian tahap II. Dalam tahapan ini pencucian kembali dilakukan, pencucian dilakukan dengan air yang mengalir yang dilakukan untuk menghilangkan bekas larutan garam pada umbi suweg. (5) tahap pengukusan. Tahap ini dilakukan dengan tujuan agar zat-zat yang berbahaya pada umbi suweg dapat larut atau hilang. Tahap pengukusan dilakukan selama kurang lebih 25-30 menit. (6) tahap penjemuran. Tahap penjemuran umbi suweg dilakukan dengan memanfaatkan sinar matahari langsung. Apabila matahari terik, maka cukup diperlukan waktu selama kurang lebih 2-4 hari. (7) Setelah umbi suweg benar-benar kering, maka sudah siap untuk ditumbuk atau digiling. Kemudian diayak dengan ayakan tepung agar mendapatkan hasil tepung yang maksimal. (8) Setelah tepung umbi suweg diayak dan sudah mendapatkan hasil yang maksimal maka tahap berikutnya adalah tahap pengemasan. Tepung umbi suweg dikemas dengan menggunakan plastik atau wadah yang tertutup rapat untuk menjaga kualitas tepung umbi suweg.

Dari hasil pembuatan tepung umbi suweg ini, didapatkan hasil yaitu warna tepung umbi suweg putih kecoklatan, aroma yang dihasilkan yaitu aroma yang kuat dan aroma khas dari umbi suweg, serta tekstur tepung umbi suweg halus.

Berdasarkan hasil uji laboratorium yang dilaksanakan di Fakultas Teknologi Pangan Universitas Udayana yang meliputi parameter air, abu, proksimat (protein, lemak, karbohidrat), pati dan kalori, didapatkan hasil sebagai berikut : 
Jurnal Bosaparis: Pendidikan Kesejahteraan Keluarga

Volume 9, Nomor 3, November 2018

Tabel 4. Kandungan gizi tepung umbi suweg

\begin{tabular}{clc}
\hline NO & \multicolumn{1}{c}{ ANALISIS } & $\begin{array}{c}\text { KANDUNGAN (\%) } \\
\text { (per } \mathbf{1 0 0} \mathbf{~ g})\end{array}$ \\
\hline 1 & Air & $11,98 \%$ \\
\hline 2 & Abu & $4,32 \%$ \\
\hline 3 & Protein & $5,44 \%$ \\
\hline 4 & Lemak & $1,80 \%$ \\
\hline 5 & Karbohidrat & $76,42 \%$ \\
\hline 6 & Pati & $56,07 \%$ \\
\hline 7 & Kalori & $343,7886 \mathrm{kkal}$ \\
\hline Sumber : Uji Laboratorium Universitas Udayana Teknologi Pangan 2018
\end{tabular}

Berikut ini disajikan hasil uji kualitas tepung umbi suweg dari segi warna, aroma dan tekstur. Dan hasil rumus pedoman konversi skala 3. Hasil dapat dilihat pada tabel 5 dan 6 berikut ini.

Tabel 5. Hasil tabulasi data uji kualitas

\begin{tabular}{cccc}
\hline Panelis & Warna & Aroma & Tekstur \\
\hline 1 & 3 & 3 & 3 \\
\hline 2 & 3 & 3 & 2 \\
\hline 3 & 3 & 3 & 3 \\
\hline 4 & 2 & 3 & 3 \\
\hline 5 & 3 & 2 & 3 \\
\hline Total & 14 & 14 & 14 \\
\hline
\end{tabular}

Tabel 6. Hasil Uji Kualitas Tepung Umbi Suweg

\begin{tabular}{ccc}
\hline Aspek yang dinilai & Hasil & Kategori \\
\hline Warna & 2,8 & Baik \\
\hline Tekstur & 2,8 & Baik \\
\hline Aroma & 2,8 & Baik \\
\hline
\end{tabular}

Berdasarkan hasil uji kualitas tepung umbi suweg serta berdasarkan pedoman konversi skala 3, maka di peroleh hasil bahwa : a) kualitas tepung umbi suweg dilihat dari segi warna memperoleh hasil yaitu sebesar 2,8 dengan berada pada kategori baik dengan tolok ukur yang sesuai yaitu berwarna coklat muda, b) kualitas tepung umbi suweg dilihat dari segi aroma memperoleh hasil yaitu sebesar 2,8 dengan berada pada kategori baik dan dengan tolok ukur yang sesuai yaitu memiliki aroma yang kuat dan khas dari umbi suweg, c) kualitas tepung umbi suweg dilihat dari segi tekstur 
Jurnal Bosaparis: Pendidikan Kesejahteraan Keluarga

Volume 9, Nomor 3, November 2018

memperoleh hasil yaitu sebesar 2,8 dengan berada pada kategori baik dan dengan tolok ukur yang sesuai yaitu memiliki tekstur yang halus.

\section{SIMPULAN DAN SARAN}

Proses pembuatan tepung umbi suweg diawali dengan proses persiapan bahan-bahan dan juga alat yang digunakan. Tapah awal pada saat pengolahan yaitu pengupasan dan juga pengirisan yang bertujuan untuk menghilangkan bagian kulit umbi suweg dan juga mengiris umbi suweg agar mempermudah proses atau tahantahap berikutnya. Setelah itu dilakukan proses pencucian yang pertama untuk menghilangkan kotoran-kotoran yang masih menempel pada umbi suweg. Setelah dicuci bersih, proses berikutnya yang dilakukan adalah proses perendaman dengan air garam dengan tujuan untuk menghilangkan dan menetralisir kandungan-kandungan yang tidak baik dikonsumsi oleh manusia. Proses perendaman ini dilakuakan selama satu malam atau 24 jam. Setelah didiamkan selama semalam, proses berikutnya yaitu pencucian tahan 2 untuk menghilangkan sisa-sisa garam saat perendaman. Setelah itu dilakukan proses pengukusan untuk

meyakinkan bahwa mikroorganisme berbahaya yang ada pada umbi suweg telah mati. Kemudian tahap berikutnya yaitu penjemuran untuk mengurangi kadar air umbi suweg. Penjemuran dilakukan dengan bantuan sinar matahari langsung., lalu dilakukan proses penggilingan dan juga pengayakan untuk mendapatkan tekstur tepung yang baik. Terakhir proses yang dilakukan yaitu pengemasan.

Hasil uji laboratorium yang dilakukan di Universitas Udayana mendapatkan hasil yang baik. Kandungan gizi pada tepung umbi suweg terdiri dari kandungan air sebanyak $11,98 \%$, kandungan abu sebanyak $4,32 \%$, kandungan protein sebanyak 5,44\%,

kandungan lemak sebanyak 1,8\%, kandungan pati sebanyak 56,07\%, kandungan karbohidrat $76,42 \%$ dan kalori sebanyak 343,7886 kkal.

Hasil uji kualitas tepung umbi suweg dilihat dari segi warna memperoleh hasil yaitu sebesar 2,8 dengan berada pada kategori baik dengan warna yang sesuai yaitu berwarna putih kecoklatan. Sedangkan untuk hasil uji kualitas tepung umbi suweg dilihat dari segi aroma memperoleh hasil yaitu sebesar 2,8 dengan berada pada kategori baik dan dengan aroma yang sesuai yaitu memiliki aroma yang kuat dan khas dari umbi suweg. Namun terdapat beberapa kritik pada aroma tepung umbi suweg ini yaitu aroma tepung umbi suweg yang dihasilkan sangan kuat namun mengacu pada hal yang kurang baik karena aroma khas yang dihasilkan kurang sedap. Hal ini merupakan faktor bawaan dari karakteristik umbi suweg tersebut. Kemudian, hasil uji kualitas tepung umbi suweg dilihat dari segi tekstur memperoleh hasil yaitu sebesar 2,8 dengan berada pada kategori baik dan dengan tekstur yang sesuai yaitu memiliki tekstur yang halus.

Berdasarkan kesimpulan tersebut maka dapat diajukan beberapa saran yaitu : (1) Untuk memperoleh hasil tepung yang maksimal maka perlu diperhatikan pada saat proses pengeringan. Disamping itu memahami karakteristik dasar dari bahan pangan yang digunakan juga sangat penting agar pada saat proses pengolahan dilakukan metode dan penangan yang tepat dan sesuai. Diperlukannya teknik yang benar dan juga bahan tambahan yang tepat agar benar-benar dapat dipastikan bahwa tepung umbi suweg tidak memiliki racun serta rasa gatal yang berbahaya bagi tubuh. Misalnya dengan perendaman dengan air garam yang lebih lama dan juga air pada saat proses perendaman diganti secara berkala. (2) Tepung umbi suweg memiliki kandungan protein yang rendah. Sehingga tepung umbi suweg dapat digolongkan pada tepung protein rendah, dimana tepung dengan kadar protein rendah cocok diolah menjadi aneka macam kue kering. Jika ingin mengolah kue dengan memerlukan protein sedang, maka tepung umbi suweg dapat disubstitusikan dengan tepung terigu protein sedang, dengan takaran yang disesuaikan.

(3) Warna yang dihasilkan oleh tepung umbi suweg adalah berwarna putih kecoklatan. Sedangkan pada umumnya tepung 
Jurnal Bosaparis: Pendidikan Kesejahteraan Keluarga

Volume 9, Nomor 3, November 2018

berwarna putih bersih. Sehingga diperlukan teknik yang sedikit berbeda pada pengolahannya sehingga dapat dihasilkan warna yang lebih putih. Hal ini dapat dilakukan dengan cara merendam umbi suweg lebih dari 1 malam, yaitu sekitar 3-4 hari lamanya, agar didapatkan hasil warna tepung yang lebih putih.

\section{DAFTAR PUSTAKA}

Agung, A.A.G. 1999. Metodologi Penelitian Pendidikan. Pengantar Ringkas. Singaraja: Sekolah Tinggi Keguruan dan Ilmu Pendidikan Singaraja.

Ani Isnawati, 2016 "Pusat Biomedis dan

Teknologi Dasar Kesehatan” Terdapat dalam

Http://www.litbang.depkes.go.id (akses 07 April 2018)

Arikunto, Suharsimi. (2010). Prosedur Penelitian Suatu Pendekatan Praktik. Yogyakarta: Rineka Cipta.

Badan Standarisasi Nasional (SNI 19-04281989) (diakses tanggal 07 April 2018).

Bungin, Burhan. 2005. Metodologi Penelitian Kuantitatif : Komunikasi, Ekonomi, dan Kebijakan Publik serta Ilmu-ilmu Sosial Lainnya. Jakarta : Kencana.

Desak Kartika, 2017. "Substitusi Tepung Talas Kimpul Menjadi Kue Kering Sagon Ganesha. Tersedia dalam Http://ejournal.undiksha.ac.id (diakses pada tanggal 07 April 2018)

Direktorat Gizi Departemen Kesehatan R.I. 2016. Karakteristik umbi t a 1 a s k i $\mathrm{m} \mathrm{pu} 1$

Direktorat Gizi Departemen Kesehatan R.I. 2016. Kandungan gizi karbohidrat.

Emzir. 2015. Metodologi Penelitian Pendidikan Kuantitatif \& Kualitatif. Jakarta: PT Raja Grafindo Persada.
Fitri Mey, 2014. "Pemanfaatan Tepung Umbi

Garut Sebagai Pengganti Tepung Terigu Dalam Pembuatan Biskuit Tinggi Energi Protein Dengan Penambahan Tepung Kacang Merah". Universitas Sebelas Maret Volume 3

No 1. Surabaya

Juran, Herlambang.2016. “ Dimensi Kualitas Makanan” Yogyakarta: PT Kanisius

Kadek Harumini, 2015. " Uji Kualitas

Tepung Singkong". Universitas Pendidikan Ganesha. Volume 3 No 3

(hlm 26-28) Tersedia dalam Http://ejournal.undiksha.ac.id (diakses pada tanggal 07 April 2018)

Kotler, Philip. 2005. Manajemen Pemasaran. Jilid II. Edisi Kesebelas. Alih Bahasa Benyamin Molan. Jakarta. : Indeks

Koyan, 2008. Asesmen Dalam Pendidikan Singaraja. Singaraja: Universitas Pendidikan Ganesha

Nuraini, dkk. 2013. Petunjuk Praktikum Evaluasi Sensori. PS Ilmu dan Teknologi Pangan : Purwokerto

Purwo Djatmiko, 2014. Kamus Bahasa

Indonesia Lengkap. Surabaya: Anugerah

Raharjo. 2001. Penilaian Organoleptik. Bharata Karya Aksara : Jakarta

Risa,2018. Almaendah's blog Htm. Mengenal Bunga Bangkai (Amorphophallus) dan Jenisnya. Diakses pada tanggal 06 Mei 2018

Setyaningsih , Dwi, dkk. 2010. Analisis Evaluasi Sensori Untuk Industri Pangan dan Agro. IPB Press : Bogor

Sidik, Prayitno, 1979. "UnsurUnsur Seni Rupa". Terdapat pada

Soekarto, S. T. 1985. Penilaian Organoleptik. Bharata Karya Aksara : Jakarta

Southeast Asian Food And Agricultural Science and Technology (SEAFAST) Center. Diakses pada tanggal 06 Mei 2018 
Jurnal Bosaparis: Pendidikan Kesejahteraan Keluarga

Volume 9, Nomor 3, November 2018

Sri Wahyuni, ni kadek. 2017. "Proses Pembuatan Tepung Gadung Secara Tradisional". Universitas Pendidikan Ganesha.Singaraja

Sukardi. (2011). Metodologi Penelitian Pendidikan Kompetensi dan Praktiknya. Jakarta : PT. Bumi Aksara Sutomo, B, 2008. Umbi Suweg - Potensial sebagai

Pengganti Tepung Terigu. http://myhobbyblogs.com; diakses pada tanggal 06 mei 2018

Utomo, Y.S dan S.S Antarlina,. 1997. Proseding Seminar Teknologi Pangan 1997 Kajian Sifat Fisiko Kimia Pati Umbi-Umbian Selain Ubi Kayu. Balitbang: Kendalpayan Malang.

Vinsensia, dkk, 2013. "Pemanfaatan Tepung Umbi Gadung dan Tepung MOCAF Sebagai Bahan Substitusi Dalam pembuatan Mie Basah, Mie Kering dan Mie Instan". Universitas Diponegoro Volume 2 No 2 (hlm 246256). Semarang.

Winarno, F.G. 1997. Kimia Pngan dan Gizi.PT Gramedia Pustaka Utama. Jakarta.

Laboratorium Universitas Pendidikan Ganesha.2018 